Available online at: http://ejournal-balitbang.kkp.go.id/index.php/ifrj
e-mail:ifrj.puslitbangkan@ gmail.com
INDONESIANFISHERIESRESEARCHJOURNAL
Volume 24 Nomor 1 June 2018
p-ISSN: 0853-8980
e-ISSN: 2502-6569
Accreditation Number RISTEKDIKTI: 21/E/KPT/2018

\title{
THE DEVELOPMENT OF HARVEST STRATEGIES FOR TROPICAL TUNA IN INDONESIA'S ARCHIPELAGIC WATERS
}

\author{
Fayakun Satria*1 and Lilis Sadiyah ${ }^{2}$ \\ ${ }^{1}$ Research Institute for Marine Fisheries, Ministry for Marine Affairs and Fisheries, Jl. Raya Bogor No. 507, Nanggewer Mekar, \\ Cibinong, Bogor, Jawa Barat 16912, Indonesia \\ ${ }^{2}$ Center for Fisheries Research, Ministry for Marine Affairs and Fisheries, Jl. PasirPutih II, AncolTimur, Jakarta 14430, Indonesia \\ Received; March 02-2018 Received in revised from May 07-2018; Accepted June 06-2018
}

\begin{abstract}
Significant roles of the fishery in the Indonesia's archipelagic waters/IAW (FMAs 713, 714 and $715)$, with proportion of around $60 \%$ came from the IAW, and a strong residential behavior for skipjack (SKJ) and yellowfin tuna (YFT) encourage Indonesia to develop harvest strategies for the tropical tuna in the IAW. This is a priority action of the National Tuna Management Plan (NTMP) for tropical and neritic tuna. Fisheries operating in the IAW are mainly small scale commercial vessels. A specific harvest strategy framework that appropriate with the fishery characteristics has been developed. This paper describes the process of harvest strategy (HS) development for the tropical tuna in the Indonesia's archipelagic waters (FMAs 713, 714 and 715). The HS is developed scientific works (including data collection, analysis/modelling and series technical and consultative stakeholder workshops as well as expert consultancies. Four technical workshops and seven stakeholder workshops have been done between 2015 and 2017. An interim HS (consisted of management objective, limit reference point, monitoring, analysis, harvest control rule and management measure) has been determined and agreed. Continues collaboration and commitment from related stakeholders including Government, fishers, fishing association, NGOs by adopting co-mangement and participatory approach in implementing the agreed harvest strategy, through data collection and sustain supports. The time series of catch and effort data, and size data could be used to monitor the fishery, stok status and its performance.In addition, involvement of relevant international tuna experts through expert consultancies are integrated process with the technical and stakeholder workshops. This HS development process is still on-going and can be refined, as HS development is a cycle and an iterative process.
\end{abstract}

Keywords: Harvest strategy; harvest control rule; tropical tuna; archipelagic waters

\section{INTRODUCTION}

Indonesia has claimed to be an archipelagic nation through Juanda Declaration of 1957, which referring to the Law of the Sea Convention (UNCLOS). From the eleven designated Indonesia's Fisheries Management Areas (FMAs), FMAs 713, 714, 715, 716 and 717 are related to the Western and Central Pacific Fisheries Commission (WCPFC) area. FMAs 713,714 and 715 are Indonesia archipelagic waters (IAW) which not belongs to the WCPFC convention area, whereas the other two FMAs 716 and 717 that have $12 \mathrm{~nm}$ of territorial waters are also located 200 $\mathrm{nm}$ ofthe Indonesian Economic Exclusive Zone (IEEZ). The IEEZ is under the WCPFC Convention Area (WCPFC-CA) which is under the management of this commission, unlike the archipelagic waters. The IAW is under the statistical area of the WCPFC, which
Indonesia has a sovereignty rights to manage its fishery (Anon, 2017).

The IAW, FMAs 713,714 and 715 have been considered to have a higher contribution to the Indonesian tuna catch relative to the IEEZ, with proportion of around $60 \%$ came from the IAW (Anon, 2017, Satria et al., 2014; Satria et al., 2015; Satria et al., 2016; Satria et al., 2017).Fisheries operating in the IAW are mainly small scale commercial vessels using pole and line, purse seine, handline, troll line and gillnet, which highly influencing the livelihood for the small scale fishers. These vessels mostly fish using or nearby fish aggregating devices (FADs), and they targeting tropical tuna, comprised of approximately $65 \%$ skipjack (Katsuwonus pelamis - SKJ), followed by $28 \%$ yellowfin (Thunnus albacares - YFT) and $6 \%$ bigeye tuna (T. obesus - BET) in 2016 (Satria et al., 2017). 
The important and significant role of the fishery in the IAW (Anon, 2017) and a strong residential behavior for SKJ and YFT reported by Rice et al. (2014) encourage Indonesia to develop harvest strategies (HS) for the tropical tuna (SKJ, YFT and BET) in the IAW which in line with the recent conservation and management measure (CMM) 2017-01 of the WCPFC on tropical tuna. This is consistent with Indonesia's rights and commitment to the sustainable management for these nationally but also regionally important resources. Furthermore, the development and implementation of the HS is a priority action of the National Tuna Management Plan (NTMP) for tropical and neritic tuna (MMAF, 2015) as stated in the Ministerial Decree of Marine Affairs and Fisheries No. 107/2015.In addtion, there is a need and strong request from tuna industries to establish $\mathrm{HS}$ in relation to fishery certifications for tuna fishery in the IAW.Indonesia has initiated the development of HS for tropical tuna in the IAW since November 2014. The aim of developing the HS is to enable Indonesia to manage its tropical tuna fishery within its IAW with an adaptive way which can be measurable and predictable in achieving its management objective. This work is a participatory and consultative process which involved various relevant stakeholders, including central and local Governments, managers, fishing associations, industries, companies, Non-Government Organisations (NGOs), scientists and experts.

Some guidelines are available for developing HS (DAFF, 2007, Sloan et al., 2014, NZ Govt., 2011, NZ Govt., 2008) including for the limited data fishery (Dowling et al., 2015; Prince et al., 2011). Harvest strategies have been developed by Australia for Northern Prawn Fishery (Dichmont et al., 2014) and Eastern Tuna and Billfish Fisheries (Campbell \&
Dowling, 2003). However, Indonesia itself has specific fishery characteristics and yet complicated challenges facing by Indonesia including multi gears, large size of fleets and socio-economic aspects of the fishers. This is a very first attempt to the develop harvest strategy for Indonesia's tuna fishery, a specific harvest strategy framework has been developed by involvement and assistance from experts of the Commonwealth Scientific and Industrial Research Organisation (CSIRO) Australia through the West Pacific East Asia (WPEA) project. A case study of tuna fisheries in the IAW (FMAs 713, 714 and 715) will be explored as an example on developing $\mathrm{HS}$ for tropical tuna in IAW. This paper describes the process of the HS development for the tropical tuna in the Indonesia's archipelagic waters (FMAs 713, 714 and 715).

\section{MATERIALS AND METHODS}

Port-based sampling programs (or sometimes called as "port-based catch monitoring program") conducted either by Government institutions (Center for Fisheries Research and DGCF), Non-Government Organisations or tuna fishing industries between 2010 and 2015 were used within this paper. The sampling activities cover the following landing sites: Bitung, Ternate, Sorong, Fak fak, Tual, Ambon, Kendari, Sodohoa, Maumere, Larantuka, Bone, Mamuju, Majene and Gorontalo (Figure 1). The data recorded catch by species, effort data (number of days at sea) and vessel ID from different types of fishing gears catching tropical tuna. Data collected by a collaborative research project between CFR (Center for Fisheries Research) and the WCPFC has the longest time series landing data (Table 1). This data set has been annually audited by the South Pacific Community (SPC) through regular Port Sampling Data Audits.

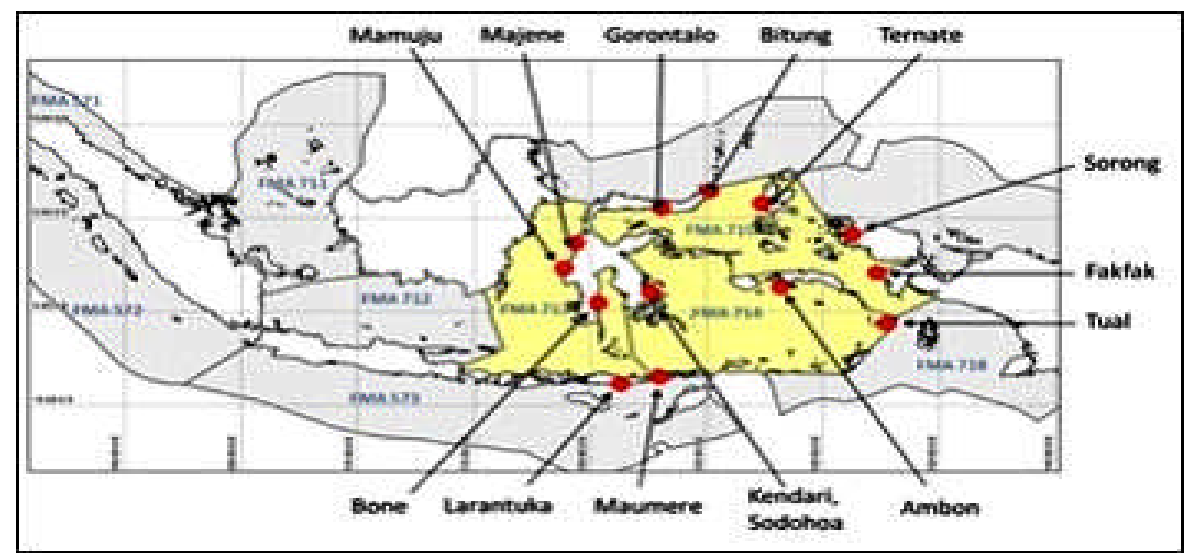

Figure 1. Map showing Locations of sampling sites (including sampling sites of CFR and WCPFC, CFR and CSIRO, and MDPI data collection programs) which covers the main tuna landings places in the Indonesia's FMAs 713 - 715. The yellow areas show the three FMAs. Modification of the Ministerial Regulation of Marine Affairs and Fisheries No. 18/ 2014 on Indonesian Fisheries Management Area (Satria \& Sadiyah, 2017). 
In addition to the port-based sampling program, National logbook and on-board observer data collected in 2016 were used in the HS work to convert the number days at sea into number of fishing days (as the number of fishing days was chosen to represent effort). Note that, the National logbook and on-board observer data prior to 2016 are still trial and effort information were incomplete. The CFR-WPCFC portbased sampling program has started to record number of fishing days as well as number of days at sea since 2016. This 2016 CFR-WCPFC data set was also used to convert the number days at sea (data prior 2016) into number of fishing days using linear regression analysis.

Minimum data requirements for the HS development were defined through the first technical workshop, which must contain at least catch (by species by gear) and effort data (number of days at sea or fishing days), and size (fish length) data, and the data are long-term series data (at minimum for three years).The data sources available were then selected using those criteria. Data sets which meet the criteria were then used for the HS work.

The HS is developed through two main processes, scientific works (including data collection, analysis/ modelling and series technical and consultative stakeholder workshops). At the same time, the involvement of relevant international tuna experts has been continuously maintained. Four technical workshops and seven stakeholder workshops have been done between 2015 and 2017. Components of $\mathrm{HS}$ consisted of monitoring, assessment/analysis, decision rule/harvest control rule (HCR), management measure and implementation (Anon, 2017).

Table 1. Summary of data sets available from FMAs 713, 714 and 715. Data sets agreed during the $2^{\text {nd }}$ stakeholder workshop for harvest strategy development are data collected from 2010-2015 (as the first attempt)

\begin{tabular}{|c|c|c|c|c|c|c|c|c|}
\hline Data series name & $\begin{array}{l}\text { Sampling } \\
\text { period }\end{array}$ & $\begin{array}{l}\text { Sampling } \\
\text { frequency }\end{array}$ & $\begin{array}{c}\text { FMA } \\
\text { coverage }\end{array}$ & $\begin{array}{l}\% \text { landing } / \text { gear } \\
\text { coverage }\end{array}$ & $\begin{array}{l}\text { Source of } \\
\text { effort/catch data }\end{array}$ & $\begin{array}{c}\text { Rel. } \\
\text { abundance? }\end{array}$ & $\begin{array}{c}\text { Size } \\
\text { indices? }\end{array}$ & On going? \\
\hline CFR-WCPFC (WPEA) & $2010->$ & Daily & $\begin{array}{l}713,714 \\
715,716 \& \\
717\end{array}$ & $\begin{array}{l}30 \% \text { of \# vessels } \\
\text { landed. } \\
\text { PL,PS,SHL,TLH,T } \\
\text { R,LHL,LL }\end{array}$ & $\begin{array}{l}\text { Effort (fishing days, } \\
\text { hooks), total catch } \\
\text { volume per port- } \\
\text { sampled vessel }\end{array}$ & $\begin{array}{c}\text { V, SKP, YFT, } \\
\text { BET, } \\
\text { ALB(Bitung) }\end{array}$ & $\sqrt{ }$ & $\sqrt{ }$ \\
\hline CFR - CSIRO (ACIAR) & $\begin{array}{l}\text { Oct } 2013 \text { - } \\
\text { Dec } 2015\end{array}$ & Daily & 714,715 & $\begin{array}{l}20 \% \text { of \# vessels } \\
\text { landed. Mainly HL } \\
\text { and TL, but also } \\
\text { PL, PS at } 4 \text { ports }\end{array}$ & $\begin{array}{l}\text { Number of fishing } \\
\text { days, catch per trip } \\
\text { recorded by } \\
\text { enumerator }\end{array}$ & & $\sqrt{ }$ & $\begin{array}{c}\text { Data collection } \\
\text { at Kendari is still } \\
\text { on-going under } \\
\text { CFR }\end{array}$ \\
\hline $\begin{array}{l}\text { RIMF (Research Institute for } \\
\text { Marine Fisheries) }\end{array}$ & 2011,2013 & $\begin{array}{l}\text { Daily, } \\
\text { sometimes } \\
\text { weekly }\end{array}$ & 714,716 & PL,PS,HL,TL & No effort data & & $\sqrt{ }$ & \\
\hline National logbook & $\begin{array}{l}2012- \\
2014\end{array}$ & Per trip & $\begin{array}{l}713,714 \\
715\end{array}$ & LL, PS, TR & No effort data & & $\sqrt{ }$ & \\
\hline $\begin{array}{l}\text { RITF (Research Institute for } \\
\text { Tuna Fisheries) }\end{array}$ & 2002 & $\begin{array}{l}2 \text { observer } \\
\text { trips only }\end{array}$ & 714 & $\mathrm{LL}$ & $\begin{array}{l}\text { Number of hooks } \\
\text { available }\end{array}$ & & & \\
\hline $\begin{array}{l}\text { AP2HI (AsosiasiPerikanan } \\
\text { Pole and Line danHandline } \\
\text { Indonesia) }\end{array}$ & 2010 -> & $\begin{array}{l}\text { Monthly } \\
\text { aggregate }\end{array}$ & $\begin{array}{l}714,715 \\
716\end{array}$ & $\mathrm{HL}, \mathrm{PL}$ & No effort data & & & $\sqrt{ }$ \\
\hline $\begin{array}{l}\text { SFP (Sustainable Fisheries } \\
\text { Partnership) }\end{array}$ & 2015 & $\begin{array}{l}\text { Not } \\
\text { everyday?? }\end{array}$ & 714 & $\mathrm{HL}$ & No effort data & & $\sqrt{ }$ & \\
\hline $\begin{array}{l}\text { MDPI } \\
\text { (MasyarakatdanPerikanan } \\
\text { Indonesia) }\end{array}$ & 2012 -> & Daily & $\begin{array}{l}713,714 \\
715\end{array}$ & $\mathrm{HL}, \mathrm{PL}$ & $\begin{array}{l}\text { Number of fishing } \\
\text { days \& catch (not } \\
\text { clear) }\end{array}$ & $\begin{array}{l}\sqrt{ }, \text { YFT, } \\
\text { SKP,?BET? }\end{array}$ & $\sqrt{ }$ & $\sqrt{ }$ \\
\hline WWF (World Wildlife Fund) & 2006 -> & Daily & 714 & $\mathrm{HL}<5 \mathrm{GT}, \mathrm{GN}$ & $\begin{array}{l}\text { Number of fishing } \\
\text { days (no available for } \\
\text { Wakatobi) }\end{array}$ & & $\sqrt{ }$ & $\sqrt{ }$ \\
\hline $\begin{array}{l}\text { PSB } \\
\text { (PerikananSamoderaBesar) }\end{array}$ & 1978-1994 & $\begin{array}{l}\text { Set by set } \\
\text { data by } \\
\text { skipper }\end{array}$ & 714 & $\begin{array}{l}\text { LL, } 1 \text { fishing } \\
\text { company }\end{array}$ & $\begin{array}{l}\text { Number of hooks } \\
\text { available \& catch per } \\
\text { set (No. of fish) }\end{array}$ & & & \\
\hline Logbook Bitung & $\begin{array}{l}2011 \text { - } \\
2013\end{array}$ & & 714,715 & PS & & & & \\
\hline $\begin{array}{l}\text { National statistics/catch } \\
\text { estimate workshop }\end{array}$ & 2002 -> & & $\begin{array}{l}713,714 \\
715\end{array}$ & all gears & $\begin{array}{l}\text { Estimated total catch } \\
\text { for each FMA }\end{array}$ & $x$ & & $\sqrt{ }$ \\
\hline
\end{tabular}

RESULTS AND DISCUSSION Results

\section{Data Collection Program and Data Selection for HS Development}

In general data collection activities for tuna fisheries prior 2010 was limited, incomplete scientific knowledege and insufficient data, hence can not be used to have accurate asessment (Gillet, 2013), since then in 2010 through the CFR - WCPFC collaborative research project (WPEA project) a port-based catch monitoring program has sucessfully established, regularly supervised and improved. In early 2014, the data collection protocol (Widodo, et al., 2013) was referred and followed by relevant NGOs and associations.

The available data sets for the HS work are mainly port-based catch monitoring programs which generally 
aimed to estimate total catch by gear by species, not really focus on effort data collection (some of the programs collected lower resolution of effort data, i.e. number of days at sea). The observer and logbook data collected prior 2016 could not be used for current HS work due to the programs were still in developing stage. However, the improved observer and logbook data collected in 2016 were used in the HS work (conversion from number of days at sea into number of fishing days).

Through series of technical and stakeholder workshops, three data sets that meet the minimum data requirements for developing $\mathrm{HS}$ were selected. These three data sets were the CFR-WCPFC port- based catch monitoring programs, CFR-CSIRO (Commonwealth Scientific and Industrial Research Organisation, Australia) port-based sampling program (collaborative research project between CFR and CSIRO funded by ACIAR-Australian Centre for International Agricultural Research), and MDPI (Masyarakat dan Perikanan Indonesia) data collection program). Number of landings by PL vessels recorded by the three data sets and its temporal coverage (by quarter) varied (Figure 2), with the CFR-WCPFC data set has the largest number of landings recorded from 2010 - 2015. Sampling activities of the three data sets (CFR - WCPFC, CFR - CSIRO and MDPI) cover the IAW (FMAs 713, 714 and 715) (Figure 2).

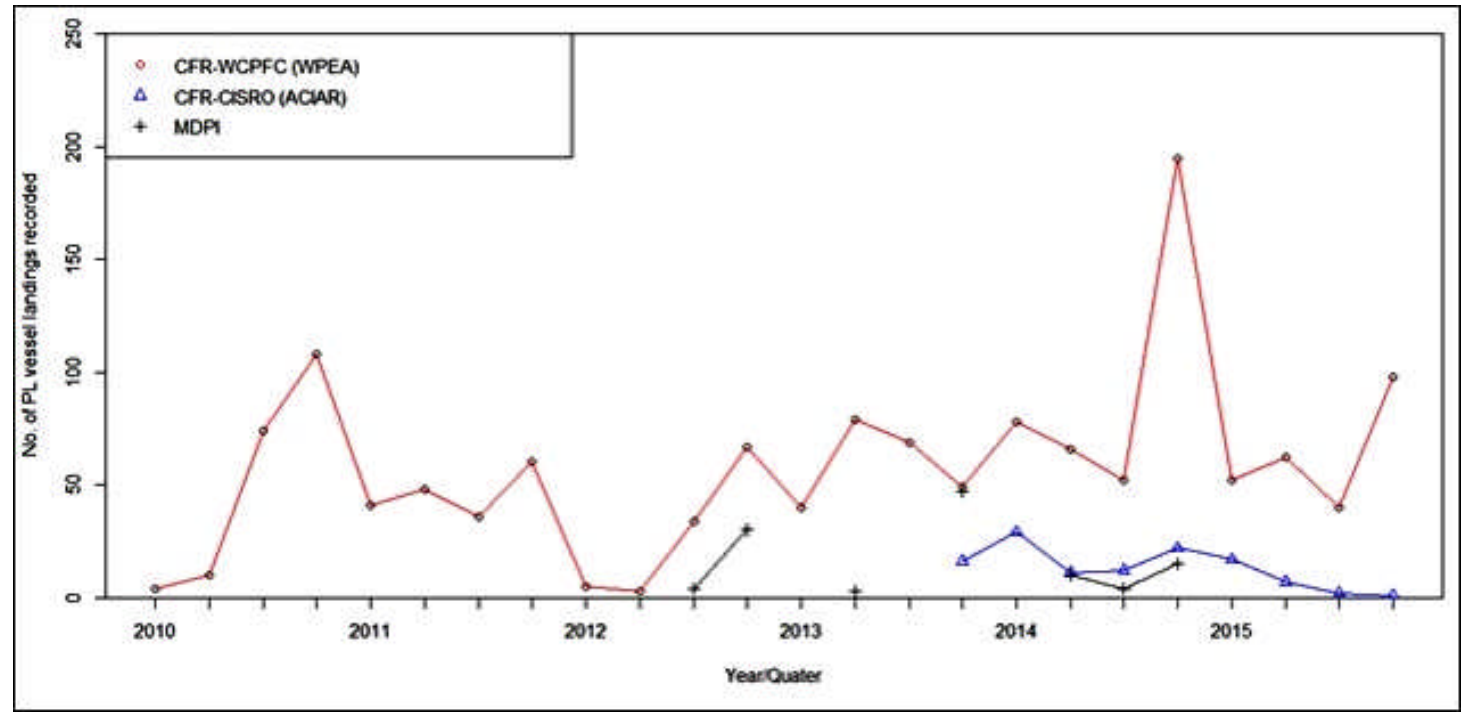

Figure 2. Number of landings by PL vessels recorded by the three data sets between 2010 and 2015 .

\section{Process of HS Development for Tropical Tuna in the IAW}

Process of HS development for the tropical tuna in the IAW is described in Figure 3. This process has been commenced with the initiation of HS inclusion in the NTMP draft and the Indonesia's statement in the WCPFC to manage its IAW in 2014. This was then followed by stakeholder and technical workshops. The $1^{\text {stand }} 2^{\text {nd }}$ stakeholder workshops were held in 2015 , with the main output is an agreement of the HS definition and framework. At the same time, the task force for the HS development was established.

In 2016, the $3^{\text {rd }}$ and $4^{\text {th }}$ stakeholder workshops were held, and 9 candidates of management objectives and 8 candidates of management measures were determined and agreed. In addition, the $1^{\text {st }}$ and $2^{\text {nd }}$ technical workshops were undertaken, which identified the data available from various sources and applying the Length-based Spawning Potential Ratio
(LB-SPR), respectively. LB-SPR is one of methods to assess stock status for data limited fishery (Hordyk et al., 2015a, b). Since the LB-SPR method was found to be inappropriate method due its assumption could not be fulfilled by the data available (Satria and Sadiyah, 2017), the data limited approach (standardised CPUE for SKJ from PL fishery and mean length) was applied. This method was advised by the international experts during the $2^{\text {nd }}$ technical workshop. The operating model (as a test bed for evaluating candidates of HS, under the process of management strategy evaluation MSE) has started to be developed but not explained in this paper. In 2017, one management objective and five management measures were agreed during the $5^{\text {th }}-7^{\text {th }}$ stakeholder workshops (using risk-based assessment). Expert consultations and training are also important and integrated part of this process. One of the essential output from the expert consultations is component of a harvest startegy that should be established, which illustrated in Figure 4. 


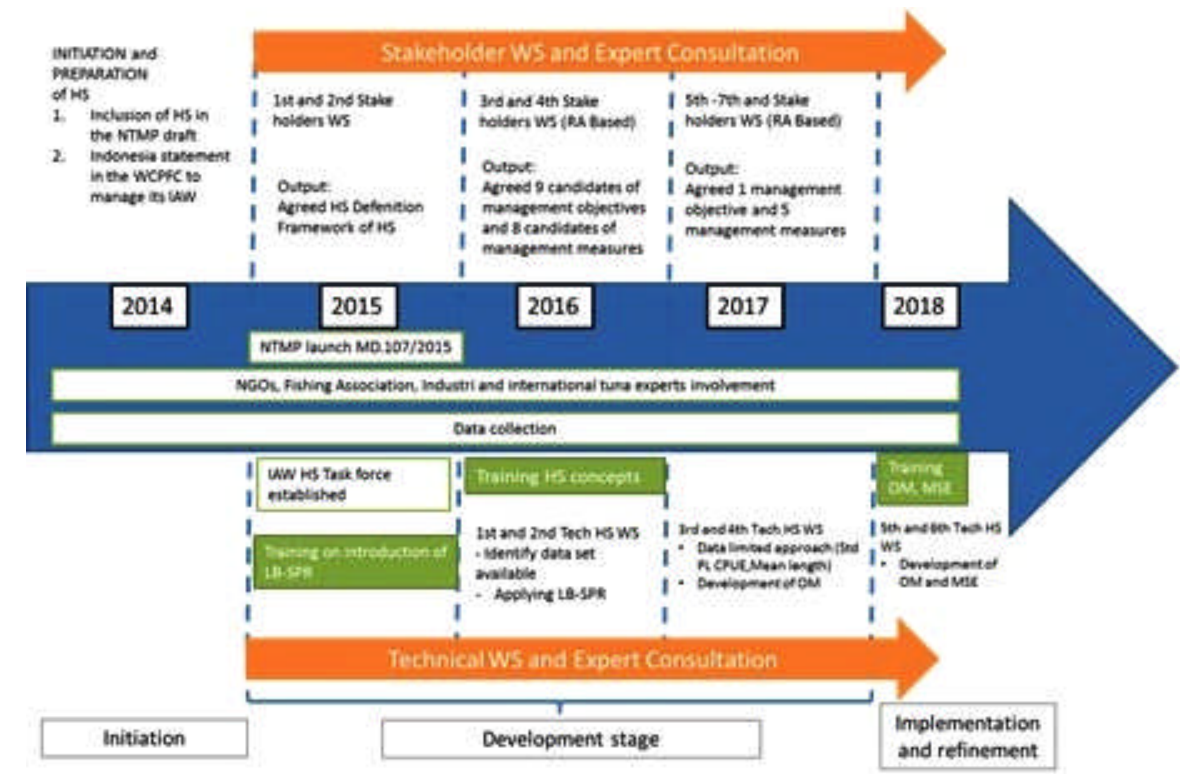

Figure 3. Process of harvest strategies development for the tropical tuna (SKJ, YFT and BET) in the Indonesia's archipelagic waters.

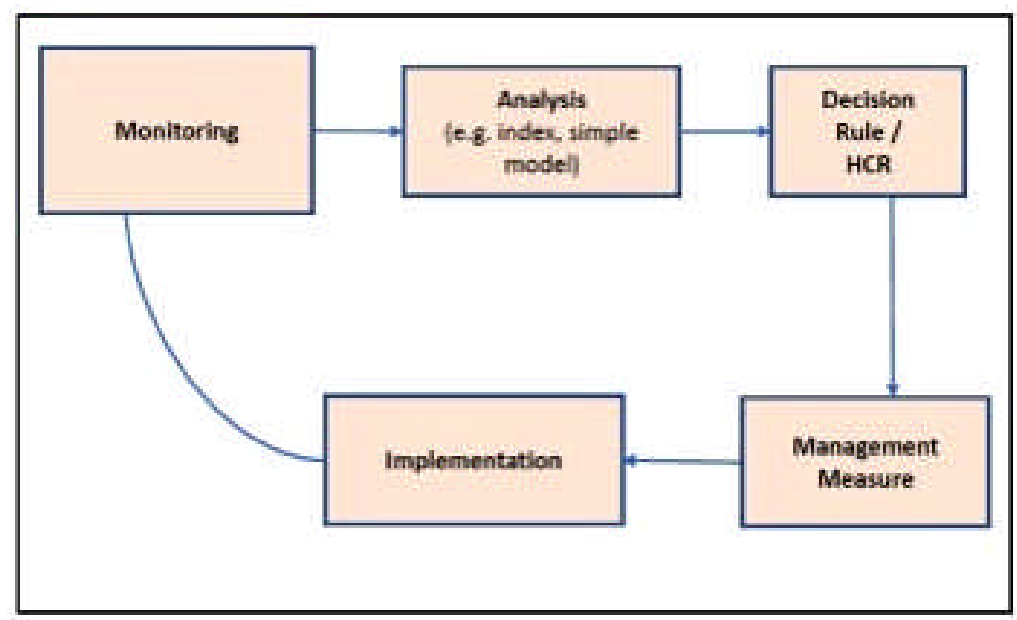

Figure 4. Illustration of four components of a harvest strategy (Monitoring, Analysis, HCR and Management Measure) and its implementation presented by Campbell Davies during the training on HS concept in 2016 at CSIRO Hobart, Australia. The implementation is to investigate the impact of the selected management measure/s of each harvest strategy candidate on the stock, which can be used as a basis to refine the harvest strategy candidate.

Components of a harvest strategy are conceptually illustrated in Figure 4. Monitoring (data collection), analysis, decision rule/harvest control rule (HCR) and management measure are the main component of a harvest strategy. Importantly, a management objective and reference points (target and limit reference points) are determined to identify each component of the HS and also used in the MSE process.

\section{Management objective, and limit and target reference points}

Seven consultative stakeholder workshops have been conducted to determine management objectives, reference point (LRP-TRP), and potential management measures. One management objective was selected during the stakeholder workshops using risk assessment (adapted from Fletcher, 2016), from nine capture fisheries development objective that referred to Article 3 Fisheries Act No. 31/2004 on Fisheries which was amended by Fisheries Act No. 45/2009. In general, the agreed management objective is to ensure the sustainability of SKJ, YFT and BET fisheries (Anon, 2017).

The limit reference point (LRP) was determined to be compatible with the WCPFC that is spawning stock biomass (SSB) above 0.2 of the unfished level with a 
probability of 90 percent (Anon, 2017). This is then adopted to the operational objective, as to maintain SSB above the LRP of $0.2 \mathrm{SSB}_{\mathrm{F}=0}$, with the probability of $90 \%$. The target reference point has not been yet agreed as this needs to further consider socioeconomic aspects of the fishery (Anon, 2017).

\section{Monitoring}

From the data sets available from the fishery in the IAW, catch per unit effort (CPUE) data and size data were the main data collected from the tropical tuna fishery that considered to be the best indicators for abundance of the tropical tuna species (i.e. PL for SKJ, HL/LL for YFT and BET). Therefore, form of monitoring for tuna fishery in the IAW is CPUE and size data. The effort data for CPUE is number of fishing days for SKJ caught by pole and line. Number of hooks is an ideal effort data for YFT and BET tuna caught by longline. In the meantime, the number of longline vessels have decreased since the enforcement of the ministerial regulation on moratorium of ex-foreign fishing vessel and fishing vessel built overseas in 2015 (Ministerial decree No. 56/Permen-KP/2014) operated in both IAW and IEEZ (FMAs 715, 716), from 127 in 2015 to 1 in 2016 (Satria et al., 2017). Making the CPUE estimation from longline fishery in the IAW is still a big challange.

\section{Assessment/Analysis - Abundance PL and LL/HL}

The assessment part could be complicated analyses (e.g. stock assessment) but could be simple analyses. Due to the limited data situation, the simple analyses, CPUE standardisation and mean size, were used. The CPUE standardisation is undertaken to estimate abundance indices for each tuna species, by applying, for example generalised linear model (GLM) or generalized additive model (GAM).

\section{Harvest Control Rule (HCR)}

Empirical harvest strategy is considered to be the most plausible for the tropical tuna in the IAW, considering the data availability. The empirical harvest strategy is based on indices of relative abundance (standardised catch rates using PL data for SKJ and LL/HL data for YFT and BET), and/or size structure of the catch, and relatively simple analysis methods, rather than the population dynamics/stock assessment models used in model-based harvest strategies. Empirical harvest strategies have the advantages of being more transparent and more easily explained to non-technical audience and being less complicated to more straightforward to implement.

\section{Management Measures}

From the 15 (fifteen) management measures stipulated in Article 3, Law No 31 Year 2004, on Fisheries, and amended by Law 45 year 2009 on Fisheries, 8 (eight) management measures were selected through selection processes at the $4^{\text {th }}$ and $5^{\text {th }}$ Stakeholder Workshop. Subsequently, a riskassessment process was completed at the $6^{\text {th }}$ Stakeholder Workshop, and the following 5 (five) priority selected management measures were selected:

a. Limit on use of Fish Aggregating Devices.

b. Spatial closures (of important spawning or nursery grounds) and temporal closures (during important events such as spawning).

c. Number of fishing days (per gear, for semi industrial and industrial vessels).

d. Number of vessels - limited entry (per gear; for semi industrial and industrial vessels through licensing, permits, taxing, royalties).

e. Total Allowable Catch (TAC) limits per Fishery Management Area.

\section{DISCUSSION}

Indonesia is facing poor situated data with the most complex fishery in the world whilts often claim being able to manage its fishery consistent with sustainable principle. Indonesia is entering a very important and critical stage to demonstrate of its first of tropical tuna HS in the Archipelagic waters which sound scientific acceptable and robust outcome. Most importantly, the $\mathrm{HS}$ is expected to be feasible and implementable. An empirical harvest strategy is considered to be the most practical for the tropical tuna fishery in the IAW, which has been developed and tested for the Australian longline fishery (Prince et al., 2011). Reasonably, a trial can be taken as fist stage followed by necessary improvement. Some other countries have also developed empirical harvest strategies and has been successful for their domestic fisheries, such as New Zealand for rock lobster fisheries (New Zealand Ministry for Primary Industries, 2016), and South Africa for sardine and anchovy fisheries (Plaganyi et al., 2007).

Eventhough data collection and monitoring have been established with strong involvement from NGOs and fishing industries it is also predicted that potential obstacle may occur to implement the HS. Insufficient commitment and lack of capacity at all levels were major constraints. Among other things, sustain participatory and support from the industry, private and independence body are important parts in 
developing and implementing the HS. An integral part for sucessfull HS is the existence of designated research and scientific unit that play an essential role in developing, maintaining and evaluating the $\mathrm{HS}$ and its performance.

The increase and continous support and participation from fishing industry, association, and NGOs, to the importance of having an apropriate monitoring and data colection to develop and implement IAW-HS has just entering an important stage. However, in order to implement the HS in the IAW it is required a national regulation as a fundamental operational measures, i.e. NTMP, which implementable and feasible. These measures shall be complied by the relevant local governments, industries and fishing communities that is consistent with the NTMP and RFMO CMMs. In addition, it is also a challenge to introduce and familiarize the IAWHS to the IOTC and WCPFC and elaborate this in the relevant CMM of these RFMOs.

The availability of data that meet the minimum requirement for developing a $\mathrm{HS}$ is an essential part that could influence the successful of the HS development and its implementation and performance. From many data sets collected by various institutions, currently only three data sets were selected to develop the HS. The continuous involvement and support from all stakeholder sectors through improvement in their data collection programs, will increase the number of data sets used in the HS development and the robustness of the HS. Once more data available, the HS can be refined, as HS development is a cycle (Dowling et al., 2015) and an iterative process. As an example, the HS (or called as Management Procedure) of southern bluefin tuna (Thunnus maccoyii-SBT) in the CCSBT has been revised in 2011 (CCSBT, 2011) due to under reporting catch (Campbell \& Kennedy, 2010).

It is recognized during the stakeholder workshops the importance of management objectives that addressing socio-economics issues such as to increase the welfare of the local fishers and its community. However it is also realized that socio economic data were not well designed, collected and recorded to support the current HS process. Hence the WS agreed to include socio economic in the future data collection and will iclude in the analyis once the data available. The five candidate management objectives agreed for the IAW HS were mostly adressing the biology and the fish stock surrounding its sustainability. With general assumption that if these agreed objectives are achieved, socio economic objectives will likely to be achieved as well.
In the HS development, the target reference point needs to be defined. The target reference point would require to consider that the IAW has a specific characteristic, located between the Pacific (under the WCPFC) and Indian (under the IOTC) Oceans and might have a connection to the two oceans. In the meantime, the target reference point for SKJ has been agreed by WCPFC is that the spawning biomass should be 0.5 estimated unfished spawning biomass on average (WCPFC, 2015), whereas IOTC has adopted the target reference point as 0.4 of estimated unfished spawning biomass (IOTC Resolution 16/02 on harvest control rules for skipjack tuna in the IOTC area of competence). Therefore, the target reference point for the SKJ in IAW will be set and tested between 0.4 and 0.5 of estimated unfished spawning biomass.

While in general it has been agreed by IOTC and WCPFC to set limit references point, the reference that should be avoided, for SKJ that the spawning biomass sholud be 0.2 of the estimated unfished spawning biomass. The management measures for highly migratory tropical tuna is heading towards limit on catch and effort for all flag states. After the limitation is taken, the performance of Harvest strategy should be able to be tested in the frame of MSE. IAW SKJ is predicted to have similar limit reference points for 0.2 of estimated unfished spawning biomassand target reference points $0.4-0.5$ of estimated unfished spawning biomass. Operationally it is required to develop a monitoring mechanism with stock indicators as dynamics reference for fishery manager to control and ensure the stocks is within the target reference points.

It is widely known that standardized CPUE can be used as an indicator to inform the manager the status of a fish stock (Maunder \& Punt, 2004, Bigelow \& Maunder, 2007, Maunder et al., 2006). Standardized CPUE that generated from operational catch and effort data are mostly not available in the poor data situation. Hence standardized LPUE (landing per unit effort) resulted from landing data in common case can be used to estimate abundance indices when catch operational data not available, for example in the Philippines tuna fishery (Bigelow et al., 2017). In addition, series of mean length data as common data collected by port sampling program also potentially be used as an indicators by managers beside the information of total catch and its species composition by gear that landed and recorded overtime. At the minimum, apropriate series data of catch, effort and size by gear and by species with well coverage that colected for more than three years will become basic requirement in developing IAW harvest strategy. These CPUE and length. 


\section{CONCLUSION}

Most cases of fisheries in Indonesia are complex and encounter limited data situation while demand sounds having appropriate and acceptable fisheries management at national and international levels. Harvest strategy is an unavoidable tool to date that demonstrates the performance of the selected fishery that can be measureable and predictable, which isnot so simple yet not so complicated, but works and implementable. Taking into account of the characteristic and complexity of the small scale tuna fishery as well as vast archipelagic area, it is required to continue collaboration and commitment from related stakeholders imcluding Government, fishers, fishing association, NGOs by adopting co-mangement and participatory approach in implementing the agreed harvest strategy. Continous data collection and sustain support is unavoidable effort to be taken by the flag state to be able to have series of data that are used to monitor the fishery, stok status and its performance.

Indonesia's tuna in archipelagic waters at current condition has more than 6 years series of port sampling data as based monitoring performance of Harvest Strategy for SKJ, YFT and BET using data of catch, mean length and CPUE.Noting the situation of limited data that deal with the source of uncertainty the management aproach should be very precautionary. Continues improvement of operational data should be continued and focused on improvement of the standardised CPUE.

National regulation for managing tuna fisheries with approprite harvest strategy is required in line with international regulation with apropriate enforcement. The involvement of the relevant experts, scientists and fishery managers is an integrated part in developing the Harvest strategy and MSE. Regular monitoring and evaluating the adopted $\mathrm{HS}$ is required and subject to be reviewed.

\section{ACKNOWLEDGEMENTS}

The authors wish to thank for the support of WPEA Project and parties involved in the HS work including WPEA-CFR enumerators, DGCF and NonGovernment Organization (especially MDPI) for their active engagement and providing the data. In addition thanks to all participants of the technical and stakeholder workshops. Special thanks to Dr. Campbell Davies, Dr. Eriko Hoshino, Dr. Richard Hillary and Mr. Craig Proctor (experts from CSIRO, Australia), Mr. Peter Williams from SPC (WCPFC Data base manager) and Dr. Sung Kwon Soh (WPEA
Project manager) for their expertise, support and assistance.

\section{REFERENCES}

Anon. (2017). Information paper on interim harvest strategies for tropical tuna in archipelagic waters of Indonesia.Presented at the Fourteenth Regular Session of the Commission. Manila, Philippines 3 - 7 December 2017. WCPFC14-2017-DP26.

Bigelow, K., Garvilles, E., \& Emperua, L. (2017). Relative abundance of yellowfin tuna for the purse seine and handline fisheries operating in the Philippines Moro Gulf (Region 12) and High Seas Pocket \#1. Presented at the Scientific Committee Thirteenth Regular Session, Rarotonga, Cook islands, 9-17 August, 2017.

Bigelow, K.A., \& Maunder, M.N. (2007) Does habitat or depth influence catch rates of pelagic species? Canadian Journal of Fisheries and Aquatic Sciences. 64: 1581-1594.

Campbell, H., \& Kennedy, J. (2010). Bioeconomic Modeling and Management of the Southern Bluefin Tuna Fishery. 12 pages. In: Proceedings of the Fifteenth Biennial Conference of the International Institute of Fisheries Economics \& Trade, July 1316, 2010, Montpellier, France: Economics of Fish Resources and Aquatic Ecosystems: Balancing Uses, Balancing Costs. Compiled by Ann L. Shriver. International Institute of Fisheries Economics \& Trade, Corvallis, Oregon, USA, 2010.

Campbell, R. A., \& Dowling, N. (2003). Development of an operating model and evaluation of harvest strategies for the Eastern Tuna and Billfish Fishery. Final report for Project 1999/107, Fisheries Research and Development Corporation, Canberra.

Commission for the Conservation of Southern Bluefin Tuna (CCSBT). (2011). Report of the Sixteenth Meeting of the Scientific Committee.19-28 July 2011, Bali, Indonesia.

Department of Agriculture, Fisheries and Forestry of Australia (DAFF). (2007). Commonwealth Fisheries Harvest Strategy Policy and Guidelines. $55 p$.

Dichmont, C. M., Jarrett, A., Hill, F., \& Brown, M. (2014). Harvest strategy for the Northern Prawn Fishery under input control. Australian Fisheries Management Authority, Canberra. 
Dowling, N. A., Dichmont, C. M., Haddon, M., Smith, D. C., Smith, A. D. M., \& Sainsbury, K. (2015). Guidelines for developing formal harvest strategies for data-poor species and fisheries. Fisheries Research, 171,130-140.

Fletcher, W. J. (2005). The application of qualitative risk assessment methodology to prioritize issues for fisheries management. ICES Journal of Marine Science, 62: 1576-1587.

Hordyk, A. R., Ono, K., Sainsbury, K.J., Loneragan, N., \& Prince, J.D. (2015a). Some explorations of the life history ratios to describe length composition, spawning-per-recruit, and the spawning potential ratio. ICES Journal of Marine Science, 72: 204 - 216.

Hordyk, A. R., Ono, K., Valencia, S.R., Loneragan, N.R., \& Prince, J.D. (2015b). A novel length-based empirical estimation method of spawning potential ratio (SPR), and tests of its performance, for smallscale, data-poor fisheries. ICES Journal of Marine Science 72: 217-231.

Maunder, M. N., \& Punt, A. E. (2004). Standardizing catch and effort data: a review of recent approaches. Fisheries Research, 70: 141-159.

Maunder, M. N., Sibert, J.R., Fonteneau, A., Hampton, J., Kleiber, P., \& Harley, S. J. (2006). Interpreting catch per unit effort data to assess the status of individual stocks and communities. ICES Journal of Marine Science, 63: 1373-1385.

New Zealand Ministry for Primary Industries, The Status of New Zealand's Fisheries 2015 (2016), http://fs.fish.govt.nz/Doc/24002/ status-of-nz-fisheries-2015.pdf.ashx.

NZ, Govt. (2008). Harvest strategy standard for New Zealand fisheries. Ministry of Fisheries, New Zealand. 25pp.

NZ, Govt. (2011). Operational guidelines for New Zealand's harvest strategy standard. Revision 1. Ministry of Fisheries, New Zealand.

Plaganyi, E. E., Rademeyer, R. A., Butterworth, D. S., Cunningham, C. L., \& Johnston, S. J. 2007. Making management procedures operational innovations implemented in South Africa. ICES Journal of Marine Science, 64: 626-632.

Prince, J.D., Dowling, N.A., Davies, C.R., Campbell, R.A., \& Kolody, D.S. (2011). A simple cost-effective and scale-less empirical approach to harvest strategies. ICES Journal of Marine Science, 68: 947-960.

Rice, J., Harley, S., Davies, N., \& Hampton, J. (2014). Stock assessment of skipjack tuna in the Western and Central Pacific Ocean. Presented at the Scientific Committee Tenth Regular Session in Majuro, Republic of the Marshall Islands 614 August 2014. WCPFC SC10 2014/SA WP 05.

Satria, F., \& Sadiyah, L. 2017. Possible use of lengthbased spawning potential ratio for skipjack (KatsuwonusPelamis) in indonesia's archipelagic waters. Indonesian Fisheries Research Journal, $23(1): 45-53$.

Satria, F., Widodo, A., Bayu, G., Tampubolon, S., Retnowati, S. D., \& Hernuryadin, Y. (2014) Annual report to the commission part 1: information on fisheries, research, and statistics. Presented at the Scientific Committee Eleventh Regular Session. Majuro, Republic of the Marshall Islands 6 - 14 August 2014. WCPFC-SC10-AR/ CCM-09.

Satria, F., Widodo, A., Bayu, G., Tampubolon, S., Retnowati, S. D., \& Hernuryadin, Y. (2015) Annual report to the commission part 1: information on fisheries, research, and statistics. Presented at the Scientific Committee Eleventh Regular Session. Pohnpei, Federated States of Micronesia 5 - 13 August 2015. WCPFC-SC11-AR/CCM-09.

Satria, F., Widodo, A., Sadiyah, L., Ignatius, Bayu, G., Tampubolon, S., Novia., \& Retnowati, S. D. (2016). Annual report to the commission part 1: information on fisheries, research, and statistics. Presented at the Scientific Committee Twelfth Regular Session. Bali, Indonesia 3 - 11 August 2016. WCPFC-SC12-AR/CCM-09.

Satria, F., Widodo, A., Sadiyah, L., Ignatius, Bayu, G., Tampubolon, S., Anas, M., \& Budiarto, A. (2017). Annual report to the commission part 1: information on fisheries, research, and statistics. Presented at the Scientific Committee Thirteenth Regular Session. Rarotonga, Cook Islands 9 - 17 August 2017. WCPFC-SC13-AR/CCM-09.

Sloan, S. R., Smith, A.D.M., Gardner, C., Crosthwaite, K., Triantafillos, L., Jeffries, B., \& Kimber, N. (2014) National Guidelines to Develop Fishery Harvest Strategies. FRDC Report - Project 2010/061. Primary Industries and Regions, South Australia, Adelaide, March. CC BY 3.0. 
WCPFC. (2015). Report of the Twelfth Regular Session of the Commission.Summary Report, the Commission for the Conservation and Management of Highly Migratory Fish Stocks in the Western and Central Pacific Ocean. Bali, Indonesia, 3-8 December 2015.
Widodo, A. A., Satria, F., Prisantoso, B. I., Mahiswara, Sedana, I. G. B., Sadiyah, L., \& Williams, P. (2013). Port Sampling Protocol. Collaboration between Research Center for Fisheries Management and Conservation and Western and Central Pacific Fisheries Commission. Research Center for Fisheries Management and Conservation, and Western and Central Pacific Fisheries Commission. ISBN 978979-1156-20-2. 